solid body, the currents mentioned above with reference to the iron must necessarily be far less strong.

"With similar modifications according to the temperature required for their liquefaction the swimming takes place with all other metals."

\section{Tycho Brahe's Portrait}

IN NATURE (vol. xv., p. 406) is published a copy of a portrait of Tycho Brahe in the possession of Dr. Crompton of Manchester. Although it seems, from the inscription in the corner, that the portrait is a contemporary one, there does not appear to me to be sufficient reason for preferring this portrait, of the origin of which nothing whatsoever is known, to others of the same date. Both Tycho's "Epistolre" and "Mechanica" contain an engraving by J. D. Geyn from the year 1586 , and if the newly-discovered portrait really (as conjectured by Dr. Crompton) should have been painted to be engraved for the "Mechanica," it can hardly have been considered a good likeness, as the engraving by Geyn was preferred. The latter is very like the portrait on 'Tycho's large wall-quadrant, of which an engraving in the "Mechanica" gives us an idea, and which Tycho himself mentions with the following words :-- "Hanc effigiem magna solertia expressit Thobias Gemperlinus eximius artifex (quem mecum Augusta Vindelicorum in Daniam olim receperam) idque tam competenter, ut vix similior dari possit." This portrait is from 1587 .

The Royal Gallery at Frederiksborg (about twenty English miles from Copenhagen) contained a fine portrait of Tycho Brahe, which unfortunately was burned in the great fire in 1859 when so much of that beautiful castle was destroyed. It agreed on the whole with the two above-mentioned portraits, while the long narrow face on the Manchester portrait shows hardly any resemblance to the features on the others. I may also add, that the fine monument erected by Tycho Brahe's heirs in the church in Prague (Teinkirche), where he was buried (of which I have seen a copy in Copenhagen), is very like Geyn's and Gemperlin's engravings.

The article which accompanies the portrait in NATURE contains several small mistakes, which perhaps also occur in Brewster's "Martyrs of Science." Tycho was not born in Sweden but in Denmark, as the province of Schonen (with the island of Hven) belonged to the latter country from ancient times and up to 1660 , and he was of an ancient Danish noble family. His castle was called "Uraniborg" (Latin Uraniburgum, the Celestial Castle), the Observatory "Stjerneborg" (Stellaburgum).

Observatory, Birr Castle, Ireland

\section{Yellow Crocuses}

CAN any of your readers elucidate this problem? When, a fortnight ago, the yellow crocuses flowered, the sparrows all at once made a terrible onslaught upon them. I found the gardener in Lincoln's Inn Gardens one day mourning over a fine line of crocus plants, every flower of which was in absolute ruins. All the work of the sparrows, he said. I have seen them, too, on the flower-boxes in my windows here frequently, tearing at the crocus blooms. Yet now, later, the blue and striped crocuses are blowing, and the sparrows leave them altogether untouched. What is there in the London bloom specially that attracts the London sparrow? The taste is, I think, peculiar to the town bird. In gardens at a distance from, and immediately around, London, I have watched pienty of yellow crocus blossoms, not one flower of which has been attacked.

Gray's Inn, April 6

AlfFRed Georgre Renshaw

\section{Tropical Forests of Hampshire}

IN Mr. J. Starkie Gardner's lecture on The Tropical Forests of Hampshire (NATURE, vol. xv. p. 232), the following statement occurs which is open, I think, to considerable question :"All the shipworms generally known to us live only in saltwater, and are so delicately organised that the slightest mixture of fresh-water instantly kills them." This sweeping assertion is partly qualified by allusion to the occurrence of a species described by Mr. George Jeffries as inhabiting fresh-water, and the fact of bored wood being found 300 miles up the Gambia River; still as Mr. Gardner speaks of these facts as a "theory" still in need of verification, I would point out that no waters are more infested with the shipworm than the deltas of tropical rivers wherein the water is often largely brackish if not potable.

My own experience is confined to the delta tangled maze of creeks, the waters of which are brackish or salt for about a third of the year, and slightly so, and even potable, during the other months. The large canoes, however, which traverse these creeks are much injured by some species of ship. worm, and so little does the easy remedy of exposing them to fresh-water answer, that the Birmese are in the habit of firing their bottoms from time to time; opportunity is taken of a high spring tide to get the boat well on shore. The ends are supported on blocks of wood, and a shallow saucer-shaped cavity is made underneath which is filled with straw or other combustible matter, which gives a fierce but short-lived flame. Fire is now applied and the bottom of the boat is for some minutes kept wrapt in flame, which steams the worms to death in their holes. I cannot recall any instances of bored wood well above the tide. way, but wherever the water is occasionally brackish, thus far the worms seem capable of settling. What species occur in Pegu I cannot say, Percival Wright has described Nausitora dunlopei from the rivers of Eastern Bengal, and it may not improbably extend to the Irawadi delta, as Novaculina gangetica and a species of Scaphula closely allied to the Gangetic species do. The two Birmese species of Scaphula are both estuary forms, whereas the type of the genus in the Ganges is found a thousand miles from the sea, which suggests the plasticily of some species, which if met with fossil would be unhesitatingly regarded as marine.

Camp, Jhilum District

$$
\text { W. THEOBALD, }
$$
Geological Survey of India

\section{Hog Wallows or Prairie Mounds}

IN NATURE (vol. xv., p. 2'74), Mr. Wallace quotes a letter from his brother in regard to the so-called Hog-wallows of California, in which their origin is ascribed to debris left at the broad foot of a retiring glacier modified by the erosion of inmumerable issuing rills, and asks if this structure is known to occur elsewhere. As $I$ have observed the same formation in many parts of the Pacific slope and have tried to explain it, I hope I may be allowed to say a few words on the subject.

The peculiar configuration of surface so well described by Mir. Wallace, is very widely diffused in America, and has been described under different names. In California the mounds are called flos-ruallows, but elsewhere they are known as Prairie monnds. This latter is the better name since they are found only in grassy, treeless, or nearly treeless regions. They occur over much of the Prairie region or "plains" east of the Rocky Mountains; also over portions of the basin region, e.g., in Arizcna; also over much of the bare grassy portions of California, e.g., along the lower foothills of the Sierra and adjacent portions or the San Joaquin plains; also over enormous areas in Middle Oregon, on the eastern slope of the Cascade mountains, an undulating grassy region; also on the level grassy Prairies about the southern end of Pugit Sound, Washington territory.

They have been ascribed to the most diverse causes. In Texas, where they are very small, Prof. Hilgard thinks they are anthills. In Arizona, where they are also imperfectly developed, Mr. Gilbert thinks they are the ruined habitations of departed Prairie dogs. In some portions of California, also, where they are small, they have been popularly ascribed to burrowing squirrels. In the Prairies, about Pugit Sound, where they are splendidly developed, their great size and extreme regularity has suggested that they are burial mounds, and that the Prairies are veritable cities of the dead. It is possible that the cause may be different in different places, but I am sure that no one who has examined them in California, and especially in Oregon and Washington, can for a moment entertain any of these theories for the Pacific slope.

In a paper "On the Structure and Age of the Cascade Moun. tains," published in the American Fournal for March and April, 1874 , p. $x 67$ and p. 259 , among some miscellaneous points suggested by the main subject in hand, $I$ discuss this one of Prairie mound. I there attribute them to surface erosion under peculiar conditions, these conditions being a bare country and a drift-soil finer and more movable above and coarser and less movable below. Erosion removes the finer top-soil, leaving it only in spots. The process once commenced, weeds and shrubs take possession of the mounds as the best soil, or sometimes as the driest spots, and hold them, preventing or retarding erosion by their roots. In some cases, perhaps in most cases, a departing vegetation, i.e., a vegetation gradually destroyed by increasing dryness, seems to be an inportant condition. For my full reasons tor holding this view I must refer the reader to my paper, but I may say in passing that in the bare hilly regions of Middle Oregon, on the 